Abstracta Iranica Abstracta Iranica

Revue bibliographique pour le domaine irano-aryen

Volume 37-38-39 | 2018

Comptes rendus des publications de 2014-2016

\title{
Bruno De Nicola, Charles Melville (eds.). The Mongols' Middle East: Continuity and Transformation in Ilkhanid Iran
}

\section{Patrick Wing}

\section{(2) OpenEdition}

1 Journals

\section{Electronic version}

URL: http://journals.openedition.org/abstractairanica/47158

DOI: $10.4000 / a b s t r a c t a i r a n i c a .47158$

ISBN: 1961-960X

ISSN: 1961-960X

Publisher:

CNRS (UMR 7528 Mondes iraniens et indiens), Éditions de l'IFRI

\section{Electronic reference}

Patrick Wing, « Bruno De Nicola, Charles Melville (eds.). The Mongols'Middle East: Continuity and Transformation in Ilkhanid Iran », Abstracta Iranica [Online], Volume 37-38-39 | 2018, document 9, Online since 30 December 2018, connection on 10 December 2020. URL : http://journals.openedition.org/ abstractairanica/47158 ; DOI : https://doi.org/10.4000/abstractairanica.47158

This text was automatically generated on 10 December 2020 .

Tous droits réservés 


\title{
Bruno De Nicola, Charles Melville (eds.). The Mongols' Middle East: Continuity and Transformation in Ilkhanid Iran
}

\author{
Patrick Wing
}

\section{REFERENCES}

Bruno De Nicola, Charles Melville (eds.). The Mongols' Middle East: Continuity and Transformation in Ilkhanid Iran. Leiden-Boston: Brill, 2016, 346 p., Maps \& illustrations

1 Editors Bruno De Nicola and Charles Melville have brought together several strands of this recent scholarship in this collection of thirteen articles. In the Introduction, the editors frame this volume as a reassessment of issues of continuity and change in Iranian history twenty-five years after the publication of Ann K. S. Lambton's Continuity and Change in Medieval Persia (1988). The contributions, many of which originated as papers presented at the World Congress for Middle Eastern Studies (WOCMES) in Barcelona in 2010, demonstrate how far the study of the Mongols in the Middle East has come since Lambton's monumental book.

The volume is divided into four parts. Part I, "The Mongol Conquest of the Middle East," consists of two articles on military matters. Part II "Internal Actors: Politics, Economy and Religion," deals with the social, economic, and religious relationships and ideologies that shaped Mongol rule after the conquests had ended. Part III, "Culture and the Arts," includes articles on music, literature, and painting, and Part IV, "Relationships with Neighboring Actors," examines the Mongols' interactions with Persians, Armenians, Chinese, and Kurdish communities within their empire and at its frontiers. Charles Melville contributes a final article as Epilogue on the collapse of the Ilkhanate. As Melville puts it, "the regime was neither one thing nor the other, and... 
old loyalties were being undermined but had not yet been replaced by new ones" ( $p$. 321).

3 Although the subjects of the contributions vary widely, there are some themes that make appearances in multiple articles. For example, Ravalde, Biran, and Kolbas each deal with one or more of the Juwaynì brothers, Shams al-Dīn and 'Alā' al-Dīn 'Atāa Malik, who had such an enormous influence on government and history writing in the Ilkhanate. In addition, Ravalde, De Nicola, Dashdondog, and James all address issues around taxation from various perspectives. Overall, the editors should be commended for bringing together such a rich variety of important contributions to the history of the Mongols. The Mongols' Middle East illustrates the wide range of approaches and modes of inquiry among scholars of the Ilkhan period, and the general vitality of the field.

\section{AUTHORS}

\section{PATRICK WING}

University of Redlands 